\title{
Fine Particulate Matter Pollution Characteristics and Source Apportionment of Changchun Atmosphere
}

Jie Tang

Jilin University

Zhuo Yang

Jilin University

Yue Tui

Jilin University

Ju Wang ( $\nabla$ wangju@jlu.edu.cn )

Jilin University

\section{Research Article}

Keywords: PM2.5, source apportionment, PMF, water-soluble ions, organic carbon, elemental carbon, inorganic element

Posted Date: July 8th, 2021

DOl: https://doi.org/10.21203/rs.3.rs-431378/v1

License: (1) (1) This work is licensed under a Creative Commons Attribution 4.0 International License. Read Full License

Version of Record: A version of this preprint was published at Environmental Science and Pollution Research on January 10th, 2022. See the published version at https://doi.org/10.1007/s11356-02117690-1. 


\title{
Fine Particulate Matter Pollution Characteristics and Source Apportionment of Changchun Atmosphere
}

\author{
Jie Tang ${ }^{1} \&$ Zhuo Yang ${ }^{1} \&$ Yue Tuil \& Ju Wang ${ }^{1}$ \\ 1. College of New Energy and Environment, Jilin University, Changchun 130012, People's Republic of China
}

\section{Abstract}

In order to study the pollution characteristics and main sources of fine particulate matter in the atmosphere of the city of Changchun, $\mathrm{PM}_{2.5}$ samples were collected during the four seasons in 2014, and representative months for each season are

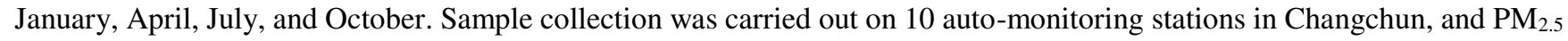
mass concentration, and its chemical components (including inorganic elements, organic carbon, elemental carbon, and water-

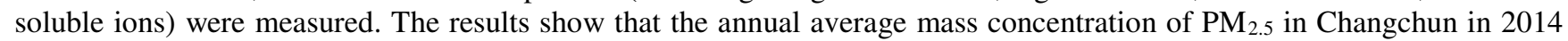
was about $66.77 \mu \mathrm{g} / \mathrm{m}^{3}$. Organic matter was the highest component in $\mathrm{PM}_{2.5}$, followed by secondary inorganic ions (SNA), mineral dust (MIN), elemental carbon (EC), and trace elements (TE). Positive Matrix Factorization (PMF) results gave seven factors, namely, industrial, biomass- and coal-burning, industrial and soil dust, motor-vehicle, soil and secondary-ion, lightindustrial, and hybrid-automotive and -industrial sources in $\mathrm{PM}_{2.5}$, with contributing values of 18.9\%, 24.2\%, 5.7\%, 23.0\%, $11.5 \%, 13.0 \%$, and $3.6 \%$, respectively.

Keywords PM2.5 source apportionment· PMF• water-soluble ions· organic carbon· elemental carbon· inorganic element.

\section{Introduction}

Fine particulate matter, or $\mathrm{PM}_{2.5}$ (particle size 2.5 microns or less), is defined as a major global urban air pollutant and a major health risk factor (Lelieveld et al., 2015; Mukherjee and Agrawal, 2017). In December 2012, more than 300 international research institutions, including the World Health Organization, jointly released the Global Burden of Disease 2012 (GBD2010). Results showed that $\mathrm{PM}_{2.5}$ could globally cause the premature deaths of approximately 3.2 million people, including China's death toll of 1.23 million (Zhao Yang et al. 2017). Therefore, the problem of fine-particulate-matter pollution has attracted wide attention at home and abroad.

$\mathrm{PM}_{2.5}$ sources are a complex mixture of natural and anthropogenic sources. Chemical components mainly include water-soluble ions, carbon components (OC, EC), and inorganic elements (Wu Bobo et al. 2016). Primary sources include vehicle exhaust pipes, coal, and biomass combustion. Secondary sources include secondary sulfate, nitrate, and organic matter (Sun Tianle et al. 2019). In order to effectively control $\mathrm{PM}_{2.5}$ concentrations in the urban atmosphere, scientific methods must be used for $\mathrm{PM}_{2.5}$ source analysis.

As the core city of Jilin Province's Economic Zone, Changchun is fast-developing. In recent years, due to a series of reasons such as city-scale expansion, and population and vehicle increase, the pollution level of $\mathrm{PM}_{2.5}$ has been increasing, and the outlook on air quality is not optimistic. Many observational $\mathrm{PM}_{2.5}$ studies have been extensively carried out in China to understand the characteristics and sources of different chemical components in $\mathrm{PM}_{2.5}$. Many scholars have used the Positive Matrix Factorization (PMF) model to analyze the main pollution sources of $\mathrm{PM}_{2.5}$ in Tai'an, Beijing, Tianjin, and Shenzhen, but currently research on $\mathrm{PM}_{2.5}$ is mainly concentrated in the Beijing-Tianjin-Hebei and the Pearl
River Delta regions (Hong Ye et al. 2010). Previous studies on atmospheric particulate matter in Changchun have focused on $\mathrm{PM}_{10}$ and TSP. There are few studies on $\mathrm{PM}_{2.5}$ sources in Changchun, and there is a lack of longterm systematic-observation data. So, this paper selected 10 sampling sites in Changchun, sampled during the four seasons, obtained $\mathrm{PM}_{2.5}$ concentrations and its components in the representative sites in Changchun, and analyzed the sources with the PMF model in order to provide technical support for improving the air quality of Changchun. This paper fills the gap in the research of $\mathrm{PM}_{2.5}$ in Changchun, as it is of great significance to control the concentration of $\mathrm{PM}_{2.5}$ and reduce the risk of urban residents there.

\section{Material and methods}

\section{Sampling Sites}

Changchun is located at $43^{\circ} 05^{\prime} \mathrm{N}-45^{\circ} 15^{\prime} \mathrm{N}$ and $124^{\circ} 18^{\prime} \mathrm{E}-$ $127^{\circ} 05 \mathrm{E}^{\prime}$, with a total area of $20,565 \mathrm{~km}^{2}$. It has a temperate continental humid climate and is the central city of northeastern Asia's economic circle. Ten automonitoring stations were set up in Changchun, all of which are national controlling stations.

Among the 10 sites in Changchun, nine are located in the built-up area of Changchun: Daishan Park(DP), HighTech Zone Management Committee(HZMC), Economic Exploitation Zone Sanitation Office(EEZCO), Jingyuetan(JYT), Bus Factory(BF), Labor Park(LP), Food Plant(FP), Institute of Post and Telecommunications(IPT), and Garden Department (GD), a clean control site is located in the Shuangyang District of Changchun, namely, Shuaiwanzi (SWZ). The corresponding setup is shown in Table 1. 
In 2014, $\mathrm{PM}_{2.5}$ samples were collected in Changchun. In each season, representative months were selected to be January, April, July, and October. Chemical components (inorganic elements, carbonaceous components, and water-soluble ions) were measured. A medium-volume air sampler (KC-120 Particulate Sampler, China) at a flow rate of $100 \mathrm{~L} / \mathrm{min}$ was used to collect $\mathrm{PM}_{2.5}$ samples for 22 $\mathrm{h}$ daily. In order to evaluate the error of the sampling process, a blank filter membrane was arranged during the sampling process. The blank filter membrane was weighed alone and with the sampling membrane, underwent the whole process of sampling, and was then shipped back to the laboratory with the sampling membrane. The difference between blank filter mass before and after sampling should have been much smaller than the particle mass on the sampling filter; otherwise, batch-sampling monitoring data were invalid.
Samples were collected on a quartz fiber filter (90 $\mathrm{mm}$ diameter) or a cellulose filter (Teflon, $90 \mathrm{~mm}$ diameter). The filter was weighed before and after the sampling progress with a microbalance MX5 Metter Toledo. We weighed the filter in the weighing chamber for 48 hours. Balance conditions were temperature, which was controlled at $15-30{ }^{\circ} \mathrm{C}$; accuracy, controlled at $1{ }^{\circ} \mathrm{C}$; humidity, controlled at $50 \% \pm 5 \% \mathrm{RH}$; and balanced roomtemperature humidity that was consistent with the constant temperature and humidity equipment.

To assess the effects of unstable conditions, blank filters were periodically used during each sampling process, and their values were used to correct the measurements of other filters. The hourly $\mathrm{PM}_{2.5}$ concentrations of used in this paper were monitored by the Changchun central monitoring station.

Table 1. Sampling-site coordinates and functional area.

\begin{tabular}{lcc}
\hline Sampling sites & Coordinates & Sites situation \\
\hline (IPT) & $125^{\circ} 17^{\prime} 02^{\prime \prime} \mathrm{E}, 43^{\circ} 50^{\prime} 49^{\prime \prime} \mathrm{N}$ & Educational and cultural area \\
$(\mathrm{LP})$ & $125^{\circ} 21^{\prime} 56^{\prime \prime} \mathrm{E}, 43^{\circ} 52^{\prime} 28^{\prime \prime} \mathrm{N}$ & An area of business and residence \\
$(\mathrm{GD})$ & $125^{\circ} 19^{\prime} 22^{\prime \prime} \mathrm{E}, 43^{\circ} 52^{\prime} 41^{\prime \prime} \mathrm{N}$ & Located in the area of business culture and education \\
$(\mathrm{FP})$ & $125^{\circ} 18^{\prime} 42^{\prime \prime} \mathrm{E}, 43^{\circ} 55^{\prime} 04^{\prime \prime} \mathrm{N}$ & Industrial zone \\
$(\mathrm{BF})$ & $125^{\circ} 17^{\prime} 16^{\prime \prime} \mathrm{E}, 43^{\circ} 54^{\prime} 07^{\prime \prime} \mathrm{N}$ & Industrial zone \\
$(\mathrm{EEZCO})$ & $125^{\circ} 25^{\prime} 00^{\prime \prime} \mathrm{E}, 43^{\circ} 52^{\prime} 00^{\prime \prime} \mathrm{N}$ & Industrial zone \\
$(\mathrm{HZMC})$ & $125^{\circ} 15^{\prime} 00^{\prime \prime} \mathrm{E}, 43^{\circ} 49^{\prime} 00^{\prime \prime} \mathrm{N}$ & In the direction of the wind of the city \\
$(\mathrm{DP})$ & $125^{\circ} 13^{\prime} 00^{\prime \prime} \mathrm{E}, 43^{\circ} 51^{\prime} 00^{\prime \prime} \mathrm{N}$ & Industrial zone \\
$(\mathrm{JYT})$ & $125^{\circ} 27^{\prime} 38^{\prime \prime} \mathrm{E}, 43^{\circ} 47^{\prime} 26^{\prime \prime} \mathrm{N}$ & Park \\
$(\mathrm{SWZ})$ & $125^{\circ} 43^{\prime} 10^{\prime \prime} \mathrm{E}, 43^{\circ} 30^{\prime} 55^{\prime \prime} \mathrm{N}$ & Blank control \\
\hline
\end{tabular}

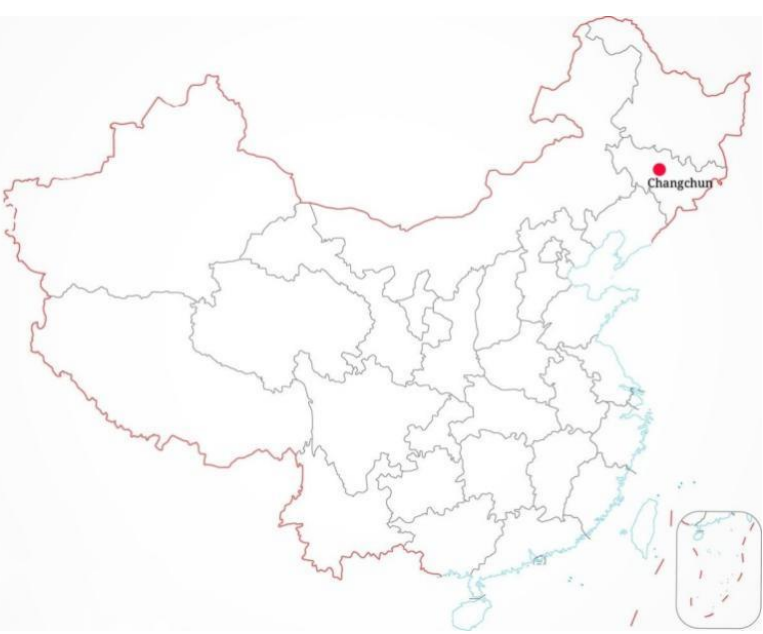

a)

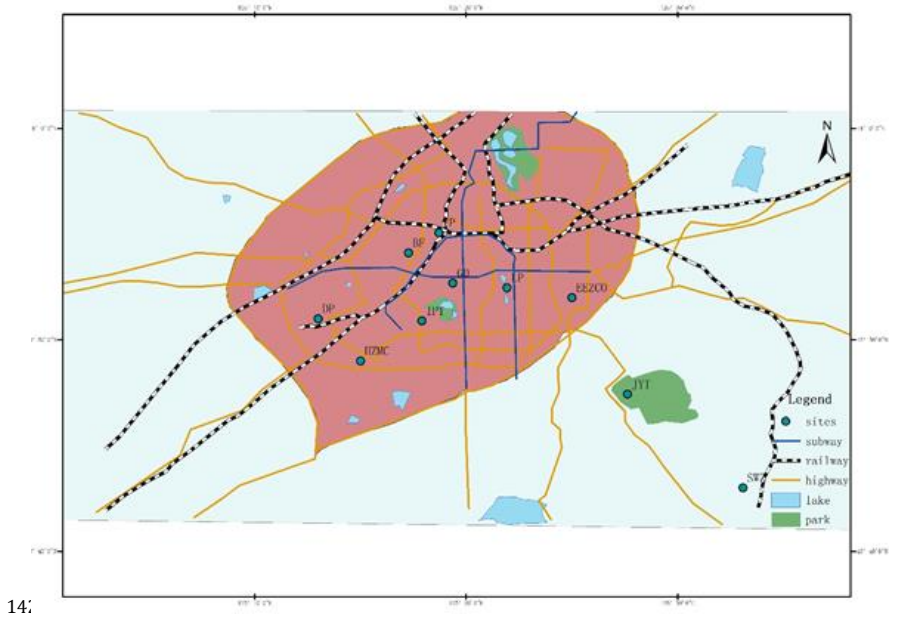

b)

Figure 1. Map (a) is the location of the study area (Changchun) in China. Map (b) is the sampling sites in Changchun. 


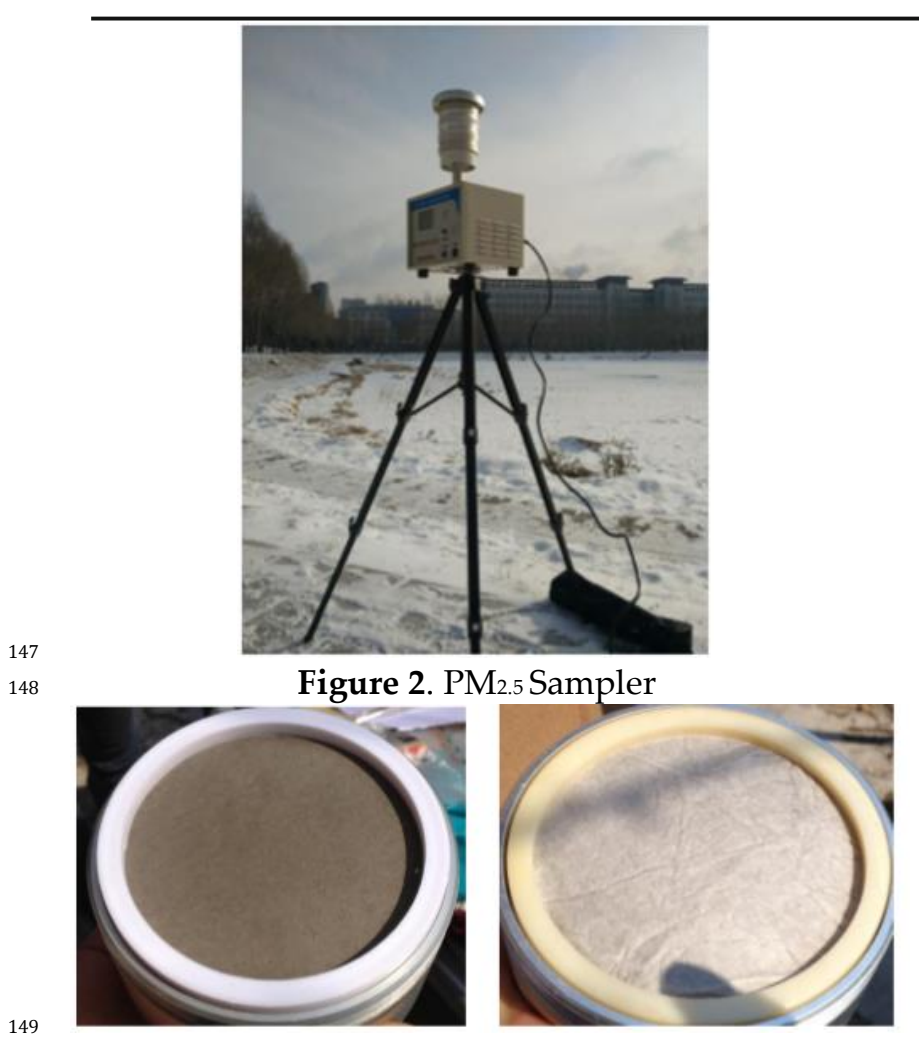

elements were determined by inductively coupled plasma mass spectrometry (ICP-MS, Agilent, America).

\section{PMF Source-Apportionment Model}

In this study, a PMF receptor model was used to analyze the main sources of $\mathrm{PM}_{2.5}$ in Changchun. The receptor model is a mathematical model for analyzing the chemical composition and physical properties of atmospheric particulate matter. It can quantitatively identify the contribution ratios of every kinds of pollution sources on the basis of factor eigenvalues or source profiles. The PMF model is a commonly used model for the source apportionment of atmospheric particulate matters. Compared with other source-analytical methods, it need not to measure the source composition profile, does not require to input the pollutant discharge inventory and photochemical reaction mechanism equations, and it can simultaneously determine the source composition profiles and source contribution ratios. The PMF model decomposes observed component-concentration matrix $X_{i j}$ into source-concentration-profile matrix $F_{k j}$ and factor-contribution-ratio matrix $G_{\text {ik }}$ (Formula 1), where $\mathrm{E}_{\mathrm{ij}}$ is the residual matrix, the difference between modelsimulation and actual-observation values. The sum of the squares of the residuals of the observation data and its error estimation ratio was defined as Q, and the solution process of the PMF model is the process of minimizing the value of $\mathrm{Q}$.

$$
\mathrm{E}_{i j}=X_{i j}-\sum_{1}^{p} G_{i k} F_{k j}
$$

The basic input to the PMF model is the mass concentration and uncertainty of the chemical components of the sample. Basic output was (a) the share and uncertainty of each chemical component in the source spectrum, (b) the contribution of each factor (source) to the overall concentration of the particulate matter, and (c) the time series of the contribution of each factor (source).

Uncertainty detection method:

concentration below detection limit $\mathrm{Unc}=$

$$
\frac{5}{6} * \mathrm{MDL}
$$

concentration above detection limit Unc $=$

$\sqrt{(\text { Error Fraction } \times \text { concentration })^{2}+(M D L)^{2}}$

This study used EPA PMF 5.0 model software released by the US Environmental Protection Agency in the calculations.

\section{Sample-Mass Closure}

Atmospheric particulate-matter mass closure can estimate the impact of aerosols from different sources on ambient air quality on the basis of the proportion of different constituent compounds. Mineral dust (MIN), elemental carbon (EC), trace elements (TE), organic matter (OM), secondary inorganic ions ( $\mathrm{SNA} ; \mathrm{SO}_{4}^{2-}, \mathrm{NO}_{3}^{-}, \mathrm{NH}_{4}^{+}$) and the rest are the mass reconstitution of $\mathrm{PM}_{2.5}$. Three kinds of water-soluble ions, EC, and TE were directly measured, and OM and MIN were calculated with many of the measured components, as follows.

It was generally assumed that there was 0280 itigiof other elements (e.g., $\mathrm{O}, \mathrm{H}$, and $\mathrm{N}$ ) per gram of carbon in the $\mathrm{OM}$ in atmospheric particulate matters, so $1.2-1.4$ represents the times of the weight of OM to OC (Fumo Yang, et al. 2004). Turpin and Lim recently tested the 
rationality of this approach and considered that it is appropriate to assume 1.4 for aerosols in urban areas, but it is more suitable for nonurban areas with more bio aerosols or secondary oxidized aerosols with 1.9-2.3 (Fumo Yang, et al. 2004). In this paper, we took 1.4 as the OC multiplier.

Soil dust in atmospheric particulate matter is usually estimated by the sum of the oxide concentrations of specific elements. It is generally assumed that soil dust is composed of the oxides of six elements (i.e., $\mathrm{SiO}_{2}, \mathrm{Al}_{2} \mathrm{O}_{3}$, $\mathrm{TiO}_{2}, \mathrm{CaO}, \mathrm{FeO}, \mathrm{Fe}_{2} \mathrm{O}_{3}$, and $\mathrm{K}_{2} \mathrm{O}$ ). It includes six of the eight most important compounds that construct the continental crust. The two other oxides, $\mathrm{Na}_{2} \mathrm{O}$ and $\mathrm{MgO}$, account for about 3\% of the mass of Earth's crust. Since Ti concentration was lower than the detection limit, MIN calculation was $\mathrm{MIN}=2.20[\mathrm{Al}]+2.49[\mathrm{Si}]+1.63[\mathrm{Ca}]+$ $2.42[\mathrm{Fe}]+1.93[\mathrm{Mg}]$.

\section{Results and Discussion}

\section{Descriptive Statistics}

The long-term average temperature of Changchun in 2018 was $7{ }^{\circ} \mathrm{C}$, the highest temperature was $36^{\circ} \mathrm{C}$, and the lowest temperature was $-32^{\circ} \mathrm{C}$. Annual precipitation was $1480.5 \mathrm{~mm}$, average daily precipitation is $4.1 \mathrm{~mm}$, and annual average humidity is $62 \%$. The main wind direction is southwestern, western, and southern (meteorological data from meteorological-data network). The average concentration of $\mathrm{PM}_{2.5}$ in Changchun in 2014 was 66.77 $\mu \mathrm{g} / \mathrm{m}^{3}$, which was 1.9 times the annual average limit value $\left(35 \mu \mathrm{g} / \mathrm{m}^{3}\right)$ in the Ambient Air Quality Standard (GB 3095-2012). Monthly mean values of $\mathrm{PM}_{2.5}$ in Changchun in 2014 are shown in Figure 4. The $\mathrm{PM}_{2.5}$ data peaked in October, and the monthly average concentration was as high as $143.76 \mu \mathrm{g} / \mathrm{m}^{3}$. The reason is that the gas pollutant emissions are high during the start-up and commissioning of the heating boiler at the end of October, and it is easy to form inversion weather in autumn, meteorological conditions which is unfavorable for the spread of gas pollutants are frequent.

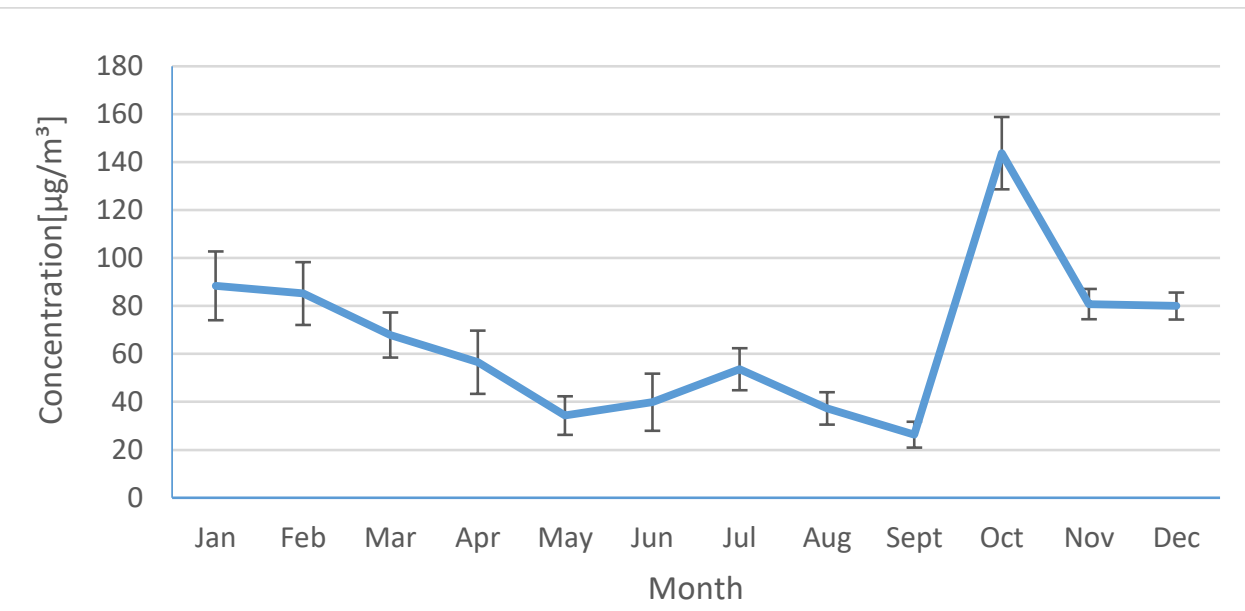

Figure 4. Monthly mean concentration changes of $\mathrm{PM}_{2.5}$ in Changchun. The error bars are represented by standard deviation.

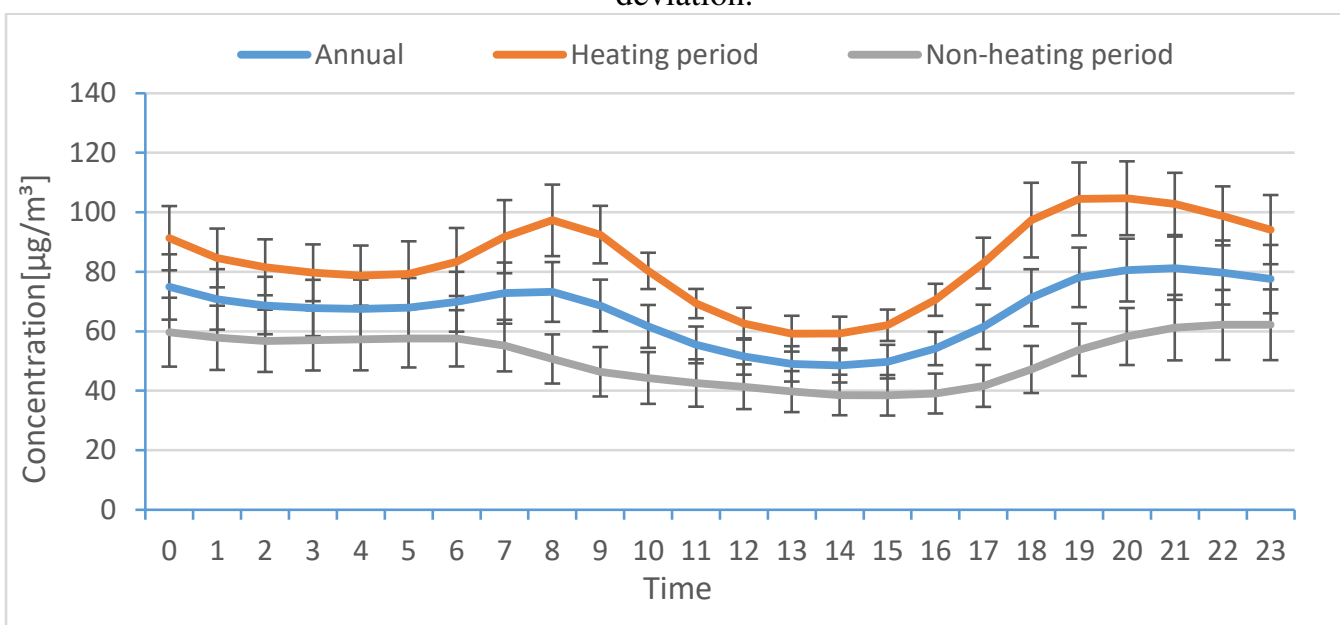

Figure 5. Comparison of Changchun's hourly $\mathrm{PM}_{2.5}$ concentration changes in heating and non-heating periods, and for the whole year. The error bars are represented by standard deviation.

The heating period in Changchun is from mid to late October to early April of the following year. It can be seen from Figure 5 that hourly $\mathrm{PM}_{2.5}$ concentrations in Changchun basically showed a bimodal change, and the heating period was significantly higher than the nonheating period. The first peak appeared in the morning from 6:00 to 9:00, during early traffic peak. The number
307 of road vehicles increased gradually, and emitted 308 pollutants increased. The second peak appeared at 19:00 309 to 21:00. The reason may be the outdoor human activities. 310 Barbecues are a common dietary feature in the Northeast. 311 During this period, residents like to have a barbecue, and 312 grilled fumes increase $\mathrm{PM}_{2.5}$ concentrations. Due to the 313 large amount of coal used during the heating period, $\mathrm{PM}_{2.5}$ 
concentrations significantly increased compared to the non-heating period.

\section{Mass closure}

From the perspective of the whole year, OM was the highest proportion of Changchun $\mathrm{PM}_{2.5}$, accounting for $38.2 \%$. From the four seasons, the seasonal variation trend for $\mathrm{OM}$ was winter > summer > autumn > spring, and $\mathrm{OM}$ proportion was the highest in winter contributed $60 \%$. The reason is that heating in Changchun begins in winter, and the amount of burnt coal increases, resulting in an increase in discharged pollutants. The reason why summer OM proportion is higher than that in spring and autumn is that the increasing of barbecues in the summer night, and the emission of a large amount of oil smoke. The seasonal trend for MIN is spring > summer > winter > autumn. Wind speed in spring and summer was higher than that in autumn and winter, which rolls up surface dust. The trend of EC in $\mathrm{PM}_{2.5}$ is autumn > spring > summer > winter, and EC proportion in autumn is significantly higher than that of the other seasons, which is due to large-scale straw burning in autumn and a relatively high motor flow. EC produced by biomass burning in the autumn and motor-vehicle exhausts have great impact on $\mathrm{PM}_{2.5}$. The seasonal change of SNA is spring $>$ autumn $>$ winter $>$ summer, and the formation of secondary particulate matter is not only related to pollutant discharge, but also wind speed, temperature, humidity, and other meteorological conditions that have related impact on the formation of secondary particulate matter. During the winter-spring transition, the increase in the number of activated molecules which is due to the gradual increase in temperature makes it easier for $\mathrm{SO}_{2}$ to be converted into sulfate ions (Zheng Y J et al. 2015). Straw burning in autumn has great influence on $\mathrm{NO}_{\mathrm{X}}$, resulting in an increase in nitrate ion content, so SNA proportion in spring and autumn is higher.

Mass closure results in Changchun are similar to those in Beijing (Yang Fumo et al. 2004) and Shenzhen (Huang Xiaofei et al. 2013), but OM proportion in Changchun $\mathrm{PM}_{2.5}$ was higher and SNA proportion was lower; the main components of $\mathrm{PM}_{2.5}$ in Shenyang are SNA, OM, and MIN (Tian Shasha, Zhang Xian, et al. 2019). This may be related to the industrial structure and meteorological conditions in Shenyang. Changchun's MIN accounts for $12 \%$, which is twice as high as that of downtown Los Angeles (Yang Fumo, He Kebin, et al. 2004). This is where characteristics of fine particulate matter pollution in Changchun and cities of the United States are different.

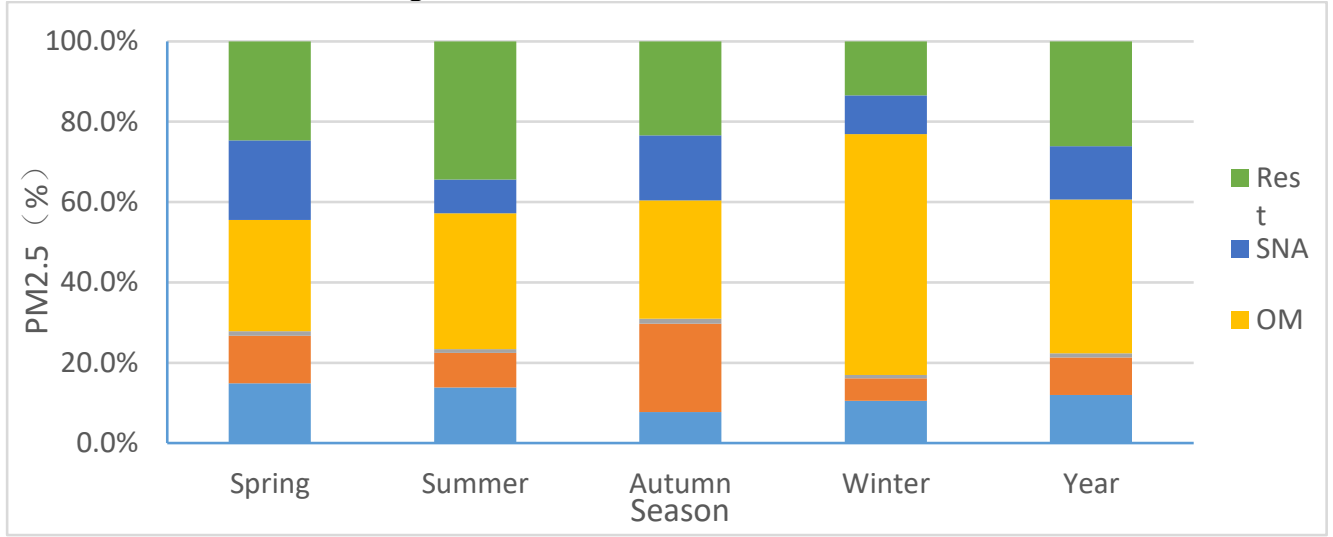

Figure 6. $\mathrm{PM}_{2.5}$ mass closure calculated on basis of analytical results for Changchun.

\section{Enrichment Factors}

The enrichment factor (EF) was used to determine the natural or believed sources of the 21 elements. The enrichment factor for element $\mathrm{X}$ is defined as

$$
\mathrm{EF}_{\mathrm{x}}=\frac{\left(C_{x} / C_{\text {ref }}\right)_{P M}}{\left(C_{x} / C_{\text {ref }}\right)_{\text {crust }}},
$$

where $C_{x}$ is the concentration of element $\mathrm{X}$, Cref is the concentration of the reference element, $\left(C_{x} / C_{r e f}\right)_{P M}$ is the ratio of the two in $\mathrm{PM}_{2.5}$, and $\left(\mathrm{C}_{\mathrm{x}} / \mathrm{C}_{\text {ref }}\right)_{\text {crust }}$ is the concentration ratio of the two in the crust. This paper chose $\mathrm{Al}$ as the reference element $=1$. The background value of soil elements was taken from background and reference values of soil chemical elements in Chinese cities. Results are shown in Figure 4.

Studies have shown that an EF $<1$ indicates that elements are not enriched mainly from natural sources such as the crust, and EF > 10 indicates that elements are enriched mainly from anthropogenic sources. According to the results, Co $(<1)$ was mainly from crust source, while $\mathrm{Mg}, \mathrm{K}, \mathrm{Ca}, \mathrm{Mn}, \mathrm{Fe}, \mathrm{Si}$ (1-10) were from both anthropogenic and crustal sources. For B, V, Cr, Ni, Cu, $\mathrm{Zn}, \mathrm{As}, \mathrm{Se}, \mathrm{Mo}, \mathrm{Cd}, \mathrm{Sn}, \mathrm{Pb}$ and $\mathrm{Si}$ (>10), they were mainly from anthropogenic source. The higher the EF, the stronger the enrichment degree. The EF of $\mathrm{B}, \mathrm{Cr}, \mathrm{Zn}, \mathrm{As}$, $\mathrm{Se}, \mathrm{Mo}, \mathrm{Cd}, \mathrm{Sn}, \mathrm{Pb}$, and $\mathrm{Hg}$ was greater than 100 , indicating strong enrichment. 


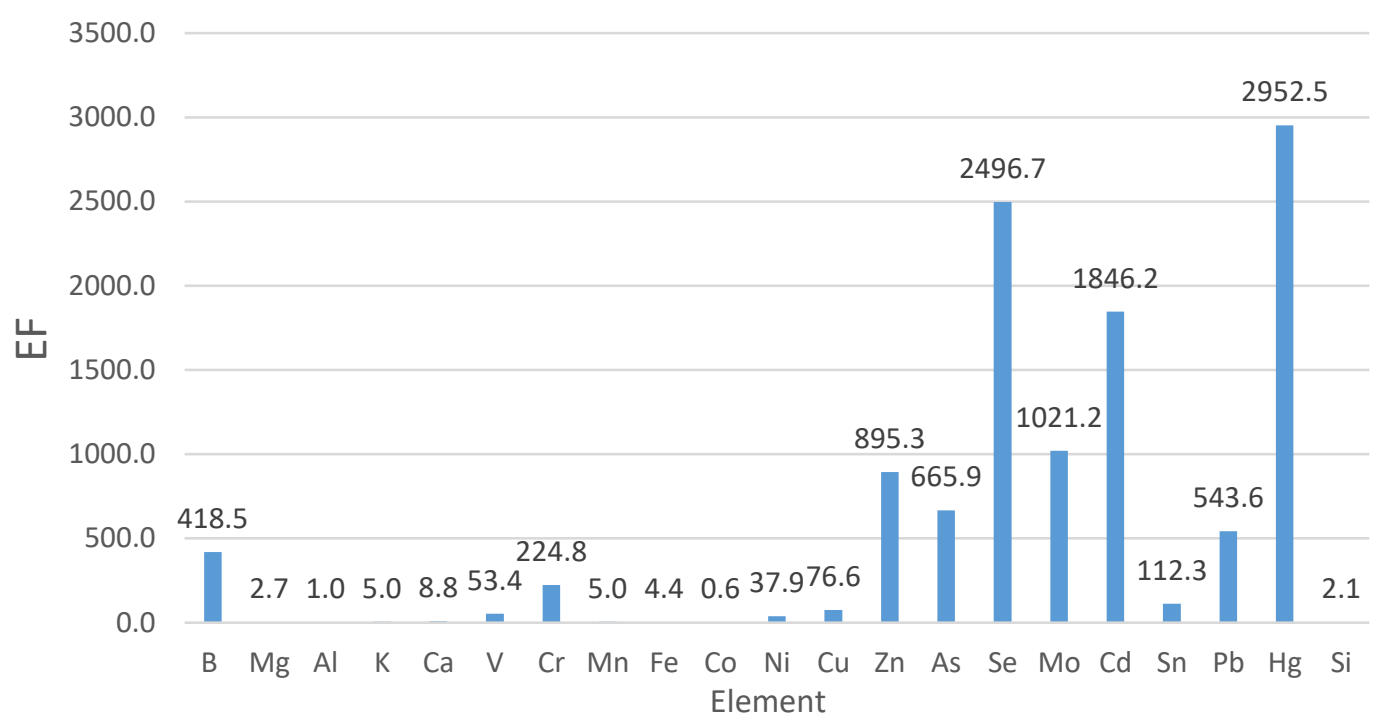

Figure 7. Enrichment-factor results of about 21 elements.

\section{Source apportionment}

The model ran in a factor of 3-9 to find the best results. The most stable solution was found when the factor number was 7. Seven factors were industrial, biomassand coal-burning, industrial and soil dust, motor-vehicle, soil and secondary-ion, light-industrial, and hybridautomotive and industrial sources. The contribution rate of each factor must be greater than $0.05 \%$, otherwise it will not be included in the determined factor.

The contribution rate of the first factor was $18.9 \%$, from which the specific gravity of $\mathrm{Zn}, \mathrm{Cd}, \mathrm{Cu}$, and $\mathrm{Mn}$ was large. $\mathrm{Zn}$ is often derived from rolling mills, $\mathrm{Cu}$ and $\mathrm{Mn}$ are related to metal smelting, and Changchun is used as a hub for automobile manufacturing, which has great demand for steel smelting. Hence, judgment factor 1 is industrial sources.

The contribution rate of the second factor was $24.2 \%$. From this, $\mathrm{Cl}^{-}$and $\mathrm{K}^{+}$had large specific gravity. $\mathrm{Cl}^{-}$can be used as a characteristic component of coal-fired emissions; and $\mathrm{K}^{+}$is a characteristic component of biomass combustion, and it is converted from $\mathrm{NO}_{\mathrm{x}}$. Straw burning has a great influence on $\mathrm{NO}_{\mathrm{x}}$. Winter heating in Changchun and straw burning in autumn have great influence on $\mathrm{PM}_{2.5}$. Judgment factor 2 is biomass-and coal-burning sources.

The contribution rate of the third factor was $5.7 \%$, in which $\mathrm{Mn}, \mathrm{Ni}$, and $\mathrm{Al}$ were relatively large. $\mathrm{Mn}$ and $\mathrm{Ni}$ are mainly from artificial sources and related to metal smelting; they belong to industrial dust, and Al mainly comes from Earth's crust. Hence, judgment factor 3 is industrial and soil dust.

The contribution rate of the fourth factor was $23.0 \%$, in which the contributions of $\mathrm{EC}, \mathrm{Pb}$, and $\mathrm{Se}$ were more prominent. $\mathrm{EC}$ is the main emission of motor fuel. $\mathrm{Pb}$ production is related to the wear of the brake components of motor vehicles. Hence, judgment factor 4 is motorvehicle sources. In Changchun, the number of motor vehicles is high, and traffic is prone to congestion. The motor-vehicle exhausts have great impact on the atmosphere.

The contribution rate of the fifth factor was $11.5 \%$, in which $\mathrm{Co}, \mathrm{Mg}^{2+}, \mathrm{SO}_{4}^{2-}$ had a high load. $\mathrm{Co}$ is a soil element, $\mathrm{Mg}^{2+}$ may be derived from road dust, and $\mathrm{SO}_{4}^{2-}$
442 is secondary ion; so, judgment factor 5 is a soil and 443 secondary-ion sources.

The sixth factor contributed $13.0 \%$, in which $\mathrm{F}^{-}$and $\mathrm{Na}^{+}$had large specific gravity, while atmospheric perfluorinated and polyfluoro-organic compounds (PFCs) are usually used as surfactants in nonstick coatings, paper, textiles, and other coatings. In this production, judgment factor 6 is light industrial sources.

The seventh factor contributed $3.6 \%$, of which $\mathrm{Hg}$, $\mathrm{V}$, and $\mathrm{Cr}$ had higher load rates. Studies showed that oil and gas used in motor vehicles contain $\mathrm{Hg}$. After combustion in motor-vehicle engines, exhaust gas containing $\mathrm{Hg}$ is discharged into the atmosphere. In addition, $\mathrm{V}$ is often added as an auxiliary material to oil products. Cr mainly comes from industrial production such as electroplating, battery manufacturing, and stainless-steel production. Hence, judgment factor 7 is hybrid-automotive and -industrial sources.

This study compared the results of $\mathrm{PM}_{2.5}$ source apportionment in Changchun with other important cities, and found that the contribution rate of coal-fired sources in Changchun is similar to that of Zhengzhou (Geng Ningbo, Wang Jia, et al. 2013), and slightly higher than that of Beijing (Wang Hailin, Zhuang Yahui, et al. 2008) and Tianjin (Kong Shaofei, Han Bin, et al. 2010), which may be related to coal-firing demands in the BeijingTianjin region. Compared with Hangzhou (Wang Jiao, Zhang Yufen, et al. 2016), the contribution rate of coalfired sources in Changchun is much higher than that in Hangzhou, which is mainly related to the non-heating season in Hangzhou, resulting in less contribution from coal-fired sources. The secondary-ion contribution rate of Changchun is significantly lower than that of Beijing, Tianjin, Shenzhen (Huang Xiaofei, Yun Hui, et al. 2013), Hangzhou, and other cities. This may be related to the relatively stable meteorological conditions in Changchun during the sampling period, which is not conducive to the formation of secondary ions. From the perspective of the contribution rate of motor vehicles, Changchun is similar to Shenzhen and Hangzhou, higher than that of Beijing, which may be related to the motor-vehicle limit policy in various regions. Due to energy-structure differences of each region, industrial structure, economic-development status, and natural conditions, the results of each study are 


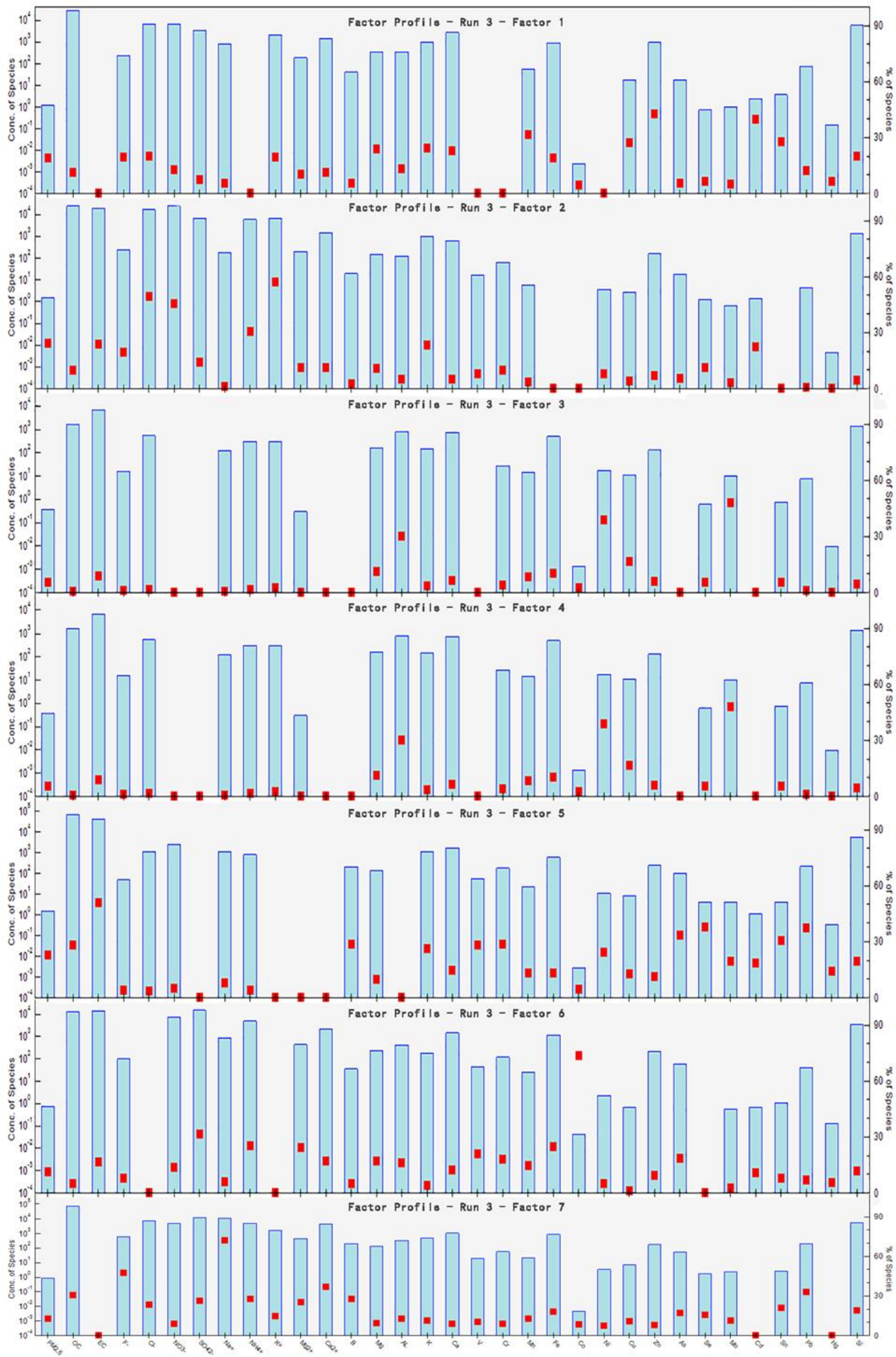

Figure 8. Factor profiles for $\mathrm{PM}_{2.5}$ resolved by Positive Matrix Factorization (PMF). The red dot represents the element's contribution to that source. Blue bars represent the concentration of elements in the source

Table 2. Background information of the sources

\begin{tabular}{|c|c|c|}
\hline $\begin{array}{l}\text { Source } \\
\text { Name } \\
\end{array}$ & $\begin{array}{c}\text { Feature } \\
\text { elements }\end{array}$ & Related Literature \\
\hline $\begin{array}{l}\text { industrial } \\
\text { sources. }\end{array}$ & $\begin{array}{c}\mathrm{Zn} \mathrm{Cu} \mathrm{Mn} \\
\text { As }\end{array}$ & $\begin{array}{l}\text { Tian S.S.; Zhang X.; Yan S.S. Characteristics and sources of PM2.5 pollution components in Shenyang } \\
\text { City, 2019; } \\
\text { Sun T.L.; Zou B.B.; Xiaofeng Huang Source Apportionment of atmospheric PM2.5 in Shenzhen, 2019; } \\
\text { Schwarz J., Petra P.; Štěpán R. Assessment of air pollution origin based on year-long parallel measurement } \\
\text { of PM2.5 and PM10 at two suburban sites in Prague, Czech Republic.2019; } \\
\text { Liu B S, Song N, Dai Q L, et al. Chemical composition and source apportionment of ambient PM2.5 } \\
\text { during the non-heating period in Taian, China, 2016; }\end{array}$ \\
\hline
\end{tabular}




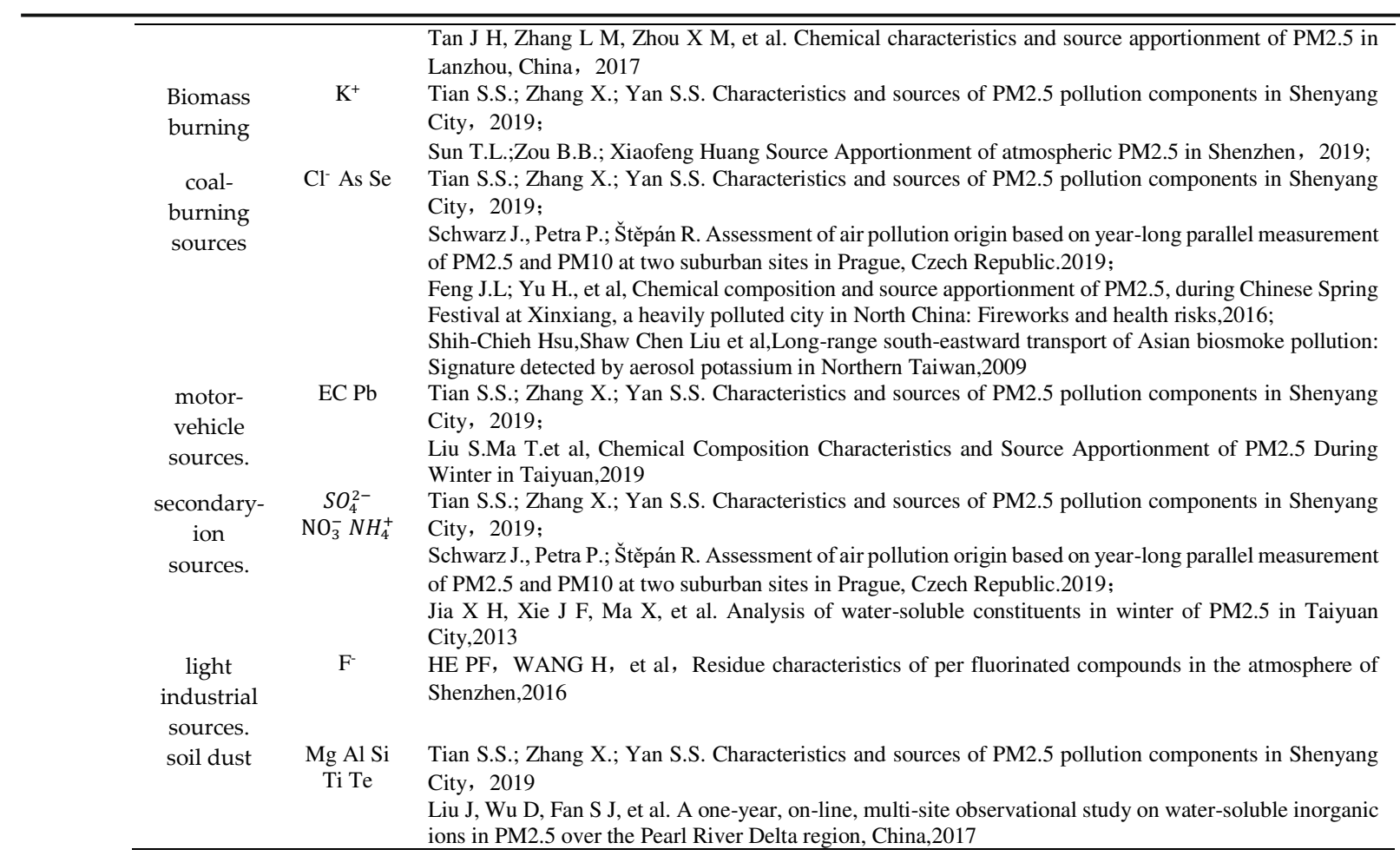

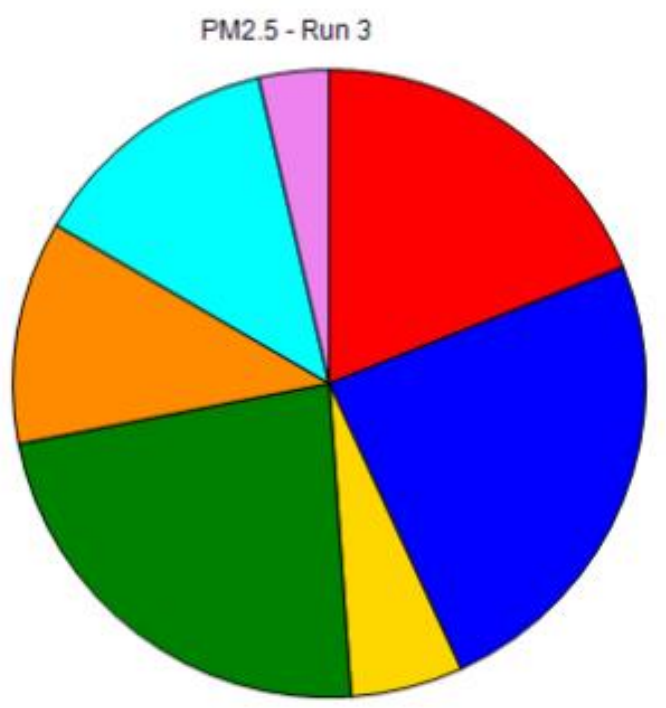

Figure 9. Average factor contribution to $\mathrm{PM}_{2.5}$ for Changchun.

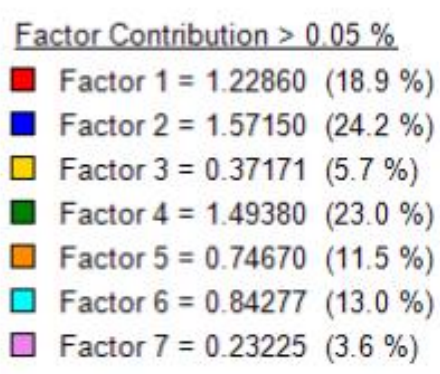

\section{Conclusion}

1. In 2014, the average mass concentration of $\mathrm{PM}_{2.5}$ in Changchun was $66.77 \mu \mathrm{g} / \mathrm{m}^{3}$, exceeding the standard by 1.9 times. The $\mathrm{PM}_{2.5}$ concentrations in the heating period was significantly higher than that in the non-heating period. For the hourly concentration, the hourly $\mathrm{PM}_{2.5}$ concentrations in Changchun basically showed double peak changes that have certain regional characteristics. Changchun should pay attention to controlling the impact of coal burning during winter heating.

2 . From the perspective of the mass closure of Changchun $\mathrm{PM}_{2.5}$, OM had the largest proportion of $\mathrm{PM}_{2.5}$, accounting for $38.2 \%$. Changchun should make efforts to control the emission of organic pollutants in the air. SNA in $\mathrm{PM}_{2.5}$ should not be ignored, accounting for $13.3 \%$. MIN accounted for $12 \%$, which is twice the city center of
515 Los Angeles. This is the difference between 516 characteristics of fine particulate pollution in Changchun 517 and big cities in the United States, which may be related 518 to the degree of urban greening. $\mathrm{PM}_{2.5}$ quality 519 reconstruction in various regions has certain regional 520 characteristics.

521 3. Results of PMF analysis showed that $\mathrm{PM}_{2.5}$ 522 sources in Changchun are divided into industrial, 523 biomass- and coal-burning, industrial and soil dust, 524 motor-vehicle, soil and secondary-ion, light-industrial, 525 and hybrid-automotive and -industrial sources, 526 accounting for $18.9 \%, 24.2 \%, 5.7 \%, 23.0 \%, 11.5 \%$, $52713.0 \%, 3.6 \%$, respectively. Compared with other cities' 528 source-apportionment results, it was found that winter 529 heating in northern regions has increased the proportion 
of coal-burning sources. Due to the low winter temperature and stable meteorological conditions in Changchun, the proportion of secondary-ion sources is relatively low compared to other cities. Motor-vehicle limit policy is implemented in the Beijing-Tianjin-Hebei region, so the vehicle sources in Changchun are relatively high.

Therefore, Changchun should: improve the utilization efficiency of coal combustion and vigorously develop clean energy; actively promote green travel, encouraging citizens to use public transport to reduce vehicle emissions; strengthen environmental management and straw remediation actions while encouraging comprehensive straw utilization; increase urban greening areas and regularly carry out groundsprinkling work, reducing the impact of ground dust on the atmosphere; and increase the management of street barbecue merchants, strictly prohibit open-air barbecue, and impose corresponding punishments on violators.

\section{Declarations}

\section{Abbreviations}

Not applicable

\section{Ethical Approval and Consent to participate Not applicable}

\section{Consent for publication}

All authors have read and agreed to the published this version of the manuscript.

\section{Availablity of supporting data \\ Not applicable}

\section{Competing interests \\ Not applicable}

\section{Funding}

This study was supported by Ecology and Environment Department of Jilin Province (NO. 2018-19 and 2019-08).

\section{Authors' contributions}

Z.Y. worked for the conceptualization, original draft writing, review and editing of the article. Y.T. worked for field sampling and filter analysis. J.W. and J.T. worked on the data curation and methodology and also worked as supervisors and directors of this study.

\section{Acknowledgements}

The authors thank the Jilin environmental monitoring station for assistance regarding data sources and sampling.

\section{Authors' information}

Jie Tang, female, professor and doctoral supervisor of College of New Energy and Environment in Jilin University.

Zhuo Yang, male, doctoral student of environmental science major in College of New Energy and Environment in Jilin University.
Yue Tui, male, master degree student of environmental science major in College of New Energy and Environment in Jilin University.

Ju Wang, female, professor and doctoral supervisor of College of New Energy and Environment in Jilin University.

\section{References}

Cesari D, Donateo A, Conte M (2016) An inter-comparison of $\mathrm{PM}_{2.5}$ at urban and urban background sites: chemical characterization and source apportionment. Atmos. Res. 174$175,106-119$.

Charlson RJ, Schwartz SE, Hales JM (1992) Climate Forcing by Anthropogenic Aerosols. Science 255(5043):423-430.

Chen B, Xu XD (2017) Climatology of wintertime long-distance transport of surface-layer air masses arriving urban Beijing in 2001-2012. Atmos. Environ. 151:70-81.

Cheng HX, Li K (2014) Background values and reference values of soil chemical elements in Chinese cities. Earth Science Frontiers (China University of Geosciences (Beijing); Peking University) 21(3):266-306.

Feng JL, Yu H, et al. (2016) Chemical composition and source apportionment of $\mathrm{PM}_{2.5}$, during Chinese Spring Festival at Xinxiang, a heavily polluted city in North China: Fireworks and health risks[J]. Atmos. Res. 182:176-188.

Gadi R, Shivani S, Sharma SK (2019) Source apportionment and health risk assessment of organic constituents in fine ambient aerosols $\left(\mathrm{PM}_{2.5}\right)$ : A complete year study over National Capital Region of India. Chemosphere.

Geng NB, Wang J, Xu YF, et al. (2013) $\mathrm{PM}_{2.5}$ in an industrial district of Zhengzhou, China: chemical composition and source apportionment[J]. Particuology 11(1): 99-109.

He PF, Wang $\mathrm{H}$, et al. (2016) Residue characteristics of perfluorinated compounds in the atmosphere of Shenzhen[J]. Environ.Sci. 37(4):1240-1247.

Hong Y, Zhou DP, Ma YY (2010) Trace element concentrations and distribution of atmospheric fine particles in the summerfall in Shenyang. China Environ. Sci. 30(7):972-979.

Hsu SC, Liu SC et al. (2009) Long-range southeastward transport of Asian biosmoke pollution: Signature detected by aerosol potassium in Northern Taiwan[J]. JOURNAL OF GEOPHYSICAL RESEARCH.

Huang XF, Yun H, Gong ZH, et al. (2013) Source apportionment and secondary organic aerosol estimation of $\mathrm{PM}_{2.5}$ in an urban atmosphere in China[J] Sci.China Earth Sci. 57(6): 13521362.

Jain S, Sharma SK, Mandal TK (2017) Source apportionment of $\mathrm{PM}_{10}$, in Delhi, India using PCA/APCS, UNMIX and PMF. Particuology S1674200117301372.

Jia XH, Xie JF, Ma X, et al. (2013) Analysis of water-soluble constituents in winter of $\mathrm{PM}_{2.5}$ in Taiyuan City[J]. China Environ.1 Sci. 33(4): 599-604.

Kong SF, Han B, Bai ZP, et al. (2010) Receptor modeling of $\mathrm{PM}_{2.5}$, $\mathrm{PM}_{10}$ and TSP in different seasons and long range transport analysis at a coastal site of Tianjin, China[J].Sci.Total Environ. 408(20): 4681-4694.

Lelieveld J, Evans JS, Fnais M, Giannadaki D, Pozzer A (2015) The contribution of outdoor air pollution sources to premature mortality on a global scale. Nature 525, 367-371.

Lim SS, Vos T, Flaxman AD (2010) A comparative risk assessment of burden of disease and injury attributable to 67 risk factors and risk factor clusters in 21 regions, 1990 2010: a systematic analysis for the Global Burden of Disease Study $2010[\mathrm{~J}]$. The Lancet 380:2224-2260.

Liu BS, Song N, Dai QL (2016) Chemical composition and source apportionment of ambient $\mathrm{PM}_{2.5}$ during the non-heating period in Taian, China. Atmos. Res. 170:23-33.

Liu J, Wu D, et al. (2017) A one-year, on-line multi-site

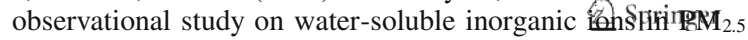
over the Pearl River Delta region, China[J]. Sci. Total Environ s601-602: 1720-1732.

Lucarelli F, Barrera V, Becagli S (2019) Combined use of daily and hourly data sets for the source apportionment of particulate matter near a waste incinerator plant. Environ. Pollut. 247:802- 
811.

Mukherjee A, Agrawal M (2017) A Global Perspective of Fine Particulate Matter Pollution and Its Health Effects. Rev. Environ. Contam. Toxicol. 244.

Pokorná P, Hovorka J, Klán M (2015) Source apportionment of size resolved particulate matter at an European air pollution hot spot. Sci. Total Environ. 502:172-183.

Pokorná P, Schwarz J, Krejci R (2018) Comparison of $\mathrm{PM}_{2.5}$ chemical composition and sources at a rural background site in Central Europe between the years 1993/1994/1995 and 2009/2010: effect of legislative transformation and economic transformation on the air quality. Environ. Pollut. 241:841851.

Schwarz J, Petra P, Štěpán R (2019) Assessment of air pollution origin based on year-long parallel measurement of $\mathrm{PM}_{2.5}$ and $\mathrm{PM}_{10}$ at two suburban sites in Prague, Czech Republic. Sci. Total Environ. 664:1107-1116

Song SK, Shon ZH, Kang YH (2019) Source apportionment of VOCs and their impact on air quality and health in the megacity of Seoul. Environ. Pollut. 247:763-774

Sowka I, Zwoździak A, Trzepla-Nabaglo K, et al. (2012) PM 2.5 elemental composition and source apportionment in a residential area of wrocŁaw, POLAND. Environ. Prot. Eng. 38: 73-79.

Sun TL, Zou BB, Huang XF (2019) Source Apportionment of atmospheric $\mathrm{PM}_{2.5}$ in Shenzhen. China Environ. Sci. 39(1): 1320.

Tan JH, Zhang LM, Zhou XM, et al. (2017) Chemical characteristics and source apportionment of $\mathrm{PM}_{2.5}$ in Lanzhou, China[J]. Sci.Total Environ. 601-602: 1743-1752.

Tian SS, Zhang X, Yan SS (2019) Characteristics and sources of $\mathrm{PM}_{2.5}$ pollution components in Shenyang City. China Environ. Sci. 39(2): 487-496
Vecchi R, Chiari M, D’Alessandro A (2008) A mass closure and PMF source apportionment study on the submicron aerosol fraction at urban sites in Italy. Atmos. Environ. 42:2240-2253.

Wang HL, Zhuang YH, Wang Y, et al. (2008) Long-term monitoring and source apportionment of $\mathrm{PM}_{2.5} / \mathrm{PM}_{10}$ in Beijing, China [J]. Journal of Environ. Sci. 20:1323-1327.

Wang J, Zhang YF, Feng YC, et al. (2016) Characterization and source apportionment of aerosol light extinction with a coupled model of CMB-IMPROVE in Hangzhou, Yangtze River Delta of China [J]. Atmos. Res. 178-179: 570-579.

Wu BB, Shen XB, Cao XY, et al. (2016) Characterization of the chemical composition of $\mathrm{PM}_{2.5}$ emitted from on-road China III and China IV diesel trucks in Beijing, China [J].Sci.Total Environ. 551/552: 579-89.

Yang FM, He KB (2004) The mass balance characteristics of Beijing $\mathrm{PM}_{2.5}$ chemical species. Environ.Chem. 23(3):326-332

Yao TT, Huang XF, He LY (2010) High time resolution observation and statistical analysis of atmospheric light extinction properties and the chemical speciation of fine particulates. Sci. China-Chem. 8, 1801-1808.

Zhao Y, Hu GR, Yu RL, et al. (2017) Concentrations and SpatialTemporal Characteristics and Source Analysis of $\mathrm{PM}_{2.5}$ in Nanchang City in 2013 [J]. Research of Environ. Sci. 30(6):854-863.

Zheng M, Zhang YJ, Yan CQ (2014) Review of $\mathrm{PM}_{2.5}$ source apportionment methods in China. Beijing Daxue Xuebao Ziran Kexue Ban/Acta Scientiarum Naturalium Universitatis Pekinensis 50(6):1141-1154.

Zheng YJ, Zhang S, Tian JZ (2015) Characteristics of water-soluble ions in $\mathrm{PM}_{2.5}$ in the spring of Qiqihar[J]. Environmental Monitoring in China 31(01):68-73. 